FEDERAL RESERVE BANK OF SAN FRANCISCO

WORKING PAPER SERIES

\title{
How Much of South Korea's Growth Miracle Can Be Explained by Trade Policy?
}

\author{
Michelle Connolly \\ Duke University \\ Kei-Mu Yi \\ Federal Reserve Bank of Philadelphia
}

September 2008

Working Paper 2008-23

http://www.frbsf.org/publications/economics/papers/2008/wp08-23bk.pdf

The views in this paper are solely the responsibility of the authors and should not be interpreted as reflecting the views of the Federal Reserve Bank of San Francisco or the Board of Governors of the Federal Reserve System. This paper was produced under the auspices of the Center for Pacific Basin Studies within the Economic Research Department of the Federal Reserve Bank of San Francisco. 


\title{
How Much of South Korea's Growth Miracle Can be Explained by Trade Policy?
}

\author{
Michelle Connolly and Kei-Mu Yi ${ }^{1}$
}

September 17, 2008

\footnotetext{
${ }^{1}$ PRELIMINARY AND INCOMPLETE. Department of Economics, Duke University, Durham, NC, 27708; connolly@duke.edu; and Research Department, Federal Reserve Bank of Philadelphia, 10 Independence Mall, Philadelphia, PA 19106; Kei-Mu.Yi@phil.frb.org. We thank participants at the SED Meetings, AEA Meetings, Princeton, New York Fed, Penn State, IMF, and Philadelphia Fed for very useful comments. Edith Ostapik and Mohan Anand provided excellent research assistance. The views expressed in this paper are those of the authors and are not necessarily reflective of views of the Federal Reserve Bank of Philadelphia or the Federal Reserve System.
} 


\begin{abstract}
South Korea's growth miracle has been well documented. A large set of institutional and policy reforms in the early 1960s is thought to have contributed to the country's extraordinary performance. In this paper, we assess the importance of one key set of policies, the trade policy reforms in Korea, as well as the concurrent GATT tariff reductions. We develop a model of neoclassical growth and trade that highlights two forces by which lower trade barriers can lead to increased per worker GDP: comparative advantage and specialization, and capital accumulation. We calibrate the model and simulate the effects of three sets of tariff reductions that occurred between the early 1962 and 1995. Our main finding is that the model can explain up to 32 percent of South Korea's catch-up to the G7 countries in output per worker in the manufacturing sector. We find that the effects of the tariff reductions taken together are about twice as large as the sum of each reduction applied individually.
\end{abstract}

JEL Classification code: F4, O110, O4, O530

Keywords: Growth, trade, calibration, multi-stage production, South Korea 


\section{Introduction}

South Korea's growth experience since the early 1960s has been widely documented and is generally considered to be a miracle. Figure 1 illustrates that in 1961, according to the Penn World Tables, South Korea's per capita GDP was $11 \%$ of that of the United States, about the same as in Cote D'Ivoire and Sri Lanka. By 1995 its per capita GDP was $49 \%$ of the United States, comparable to Portugal or Slovenia. In the intervening period, South Korea (hereafter, "Korea") experienced growth rates of real per capita GDP that averaged 6.6 percent per year.

Figure 1: Ratio of South Korea to United States GDP per capita

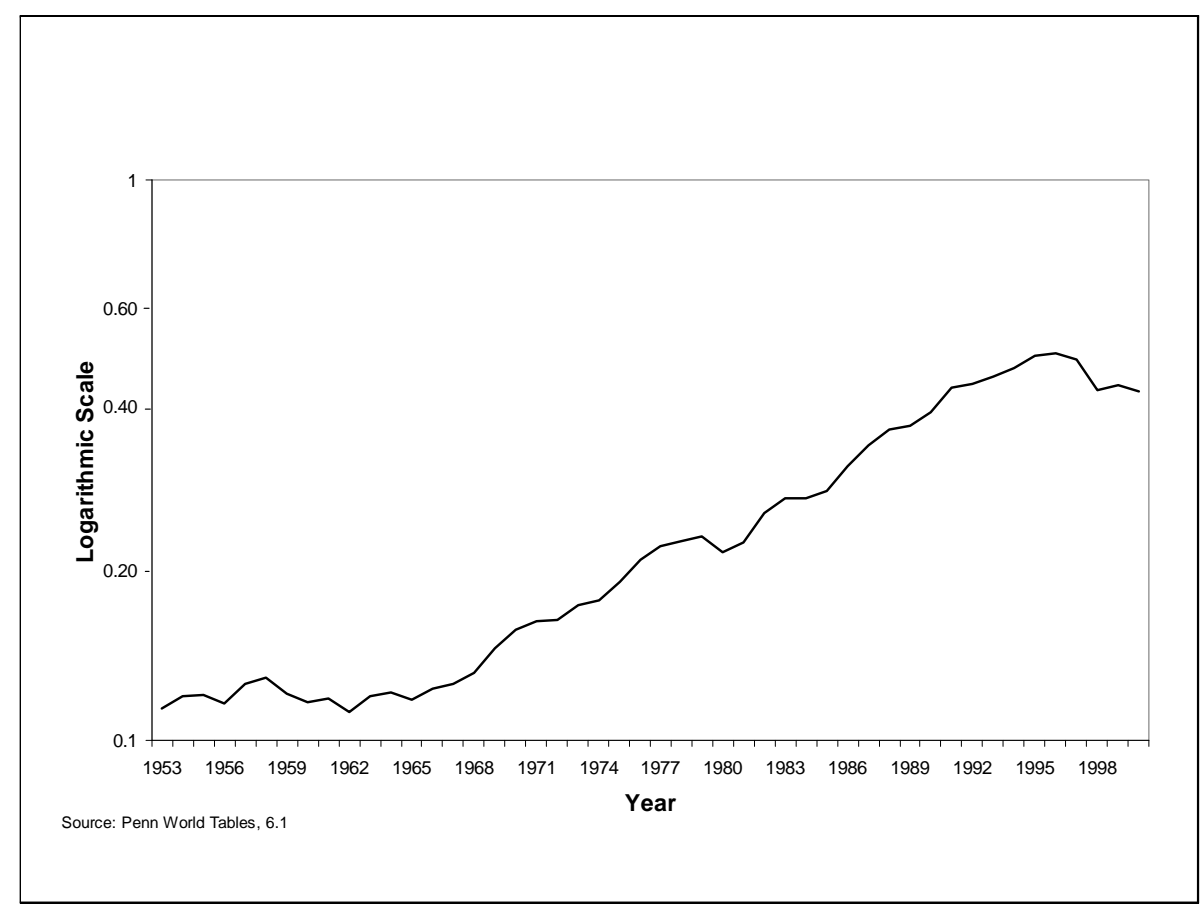

A key feature of this miracle was an enormous increase in Korea's international trade. Figure 2 shows that Korea's merchandise export share of GDP rose from just 2 percent in 1962 to 30 percent in less than 20 years. Virtually all of this increase was in manufactured goods. In 1960, only 35.2 percent of Korea's merchandise exports consisted of manufactured goods. In 1995, it was 96.9 percent. $^{1}$

The growth miracle came on the heels of a sweeping set of policy reforms following the ascension of Park Chung Hee to power in 1961. One major area of reforms was in trade policy. Park believed

\footnotetext{
${ }^{1}$ If the food, beverages and tobacco sector is counted as manufacturing, the manufacturing share of total merchandise imports was 46.6 percent in 1960 and 98.9 percent in 1995.
} 
Figure 2: South Korea Merchandise Exports and Imports

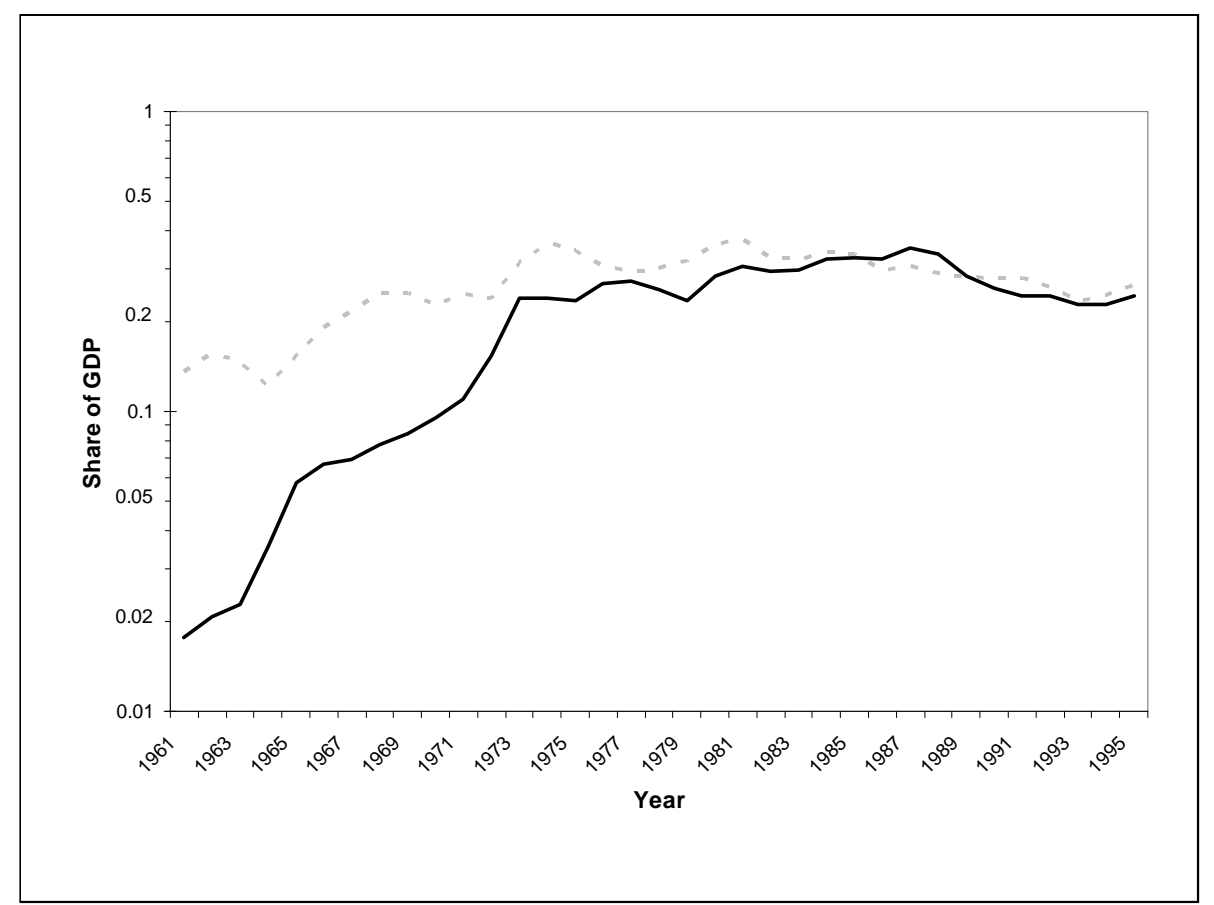

that Korea needed to start exporting, but recognized that the country had few natural resources. Consequently, trade policy shifted from largely focusing on import substitution to one focused on export expansion. Hong (1979) documents 38 reforms designed to promote exports. Of these reforms, two stand out. In the early 1960s, Korea eliminated tariffs on imported inputs and capital goods, but only as long as these imports were used to produce goods for export. The imports could not be used for production of goods sold domestically. Westphal and Kim (1977) show that, at least until 1975, this was the most important export-oriented policy. Second, beginning in the 1970s and continuing for the next two decades, Korea engaged in a broader, gradual reduction of tariff rates from about 40 percent to 13 percent. During this period, there were significant changes occurring in the global trading environment, as well. Perhaps GATT's two most important set of global tariff reductions occurred between 1968 and 1986, the Kennedy Round and the Tokyo Round.

The purpose of this paper is to assess the importance of these trade reforms in explaining Korea's growth in GDP per worker and trade between 1962 and 1995, the growth miracle period. Our methodology departs from the usual empirical methodology of the trade and growth literature. We conduct our quantitative assessment through the lens of a neoclassical model of growth and trade. The growth theory underlying our model is Cass-Koopmans. The trade theory underlying 
the model is Ricardian; relative productivity differences across countries helps determine differences in comparative advantage. Two additional features of the model are that some goods are produced in multiple stages and investment goods are tradable. These features allow the calibrated model to capture important features of the Korean data.

In the model, lower tariffs raise efficiency because it facilitates specialization. The presence of multiple stages of production deepens the extent of specialization. Countries specialize by stages, rather than by goods. The efficiency gains raise aggregate total factor productivity even though there are no intrinsic increases in the productivity of any individual good. In addition, lower tariffs generate increased imports of investment goods occurs. The total factor productivity (TFP) gains and capital accumulation ensuing from the trade liberalization leads to increases in per capita GDP.

We calibrate the model to match key features of the Korea's manufacturing sector vis-a-vis the G7 countries in 1962 and 1963. We then simulate the tariff reductions mentioned above. Our main findings are as follows. Taken together, the tariff reductions can explain up to 32 percent of Korea's catch-up in manufacturing output per worker. Both aggregate TFP gains (62 percent) and capital accumulation (38 percent) contribute to the catch-up. Interestingly, we find that the effect of the three trade policies taken together is almost twice as large as the sum of the effect from each policy applied separately. There is a large interaction effect. In terms of individual policies, the broad Korea tariff reduction has the greatest effect on the catch-up. We also show that the presence of multiple stages of production and imported investment goods are very important in explaining both the catch-up and the growth in trade.

The role of trade policy in affecting long run growth is a story involving macroeconomics, development economics, and international economics. Economists from each of these sub-disciplines have approached this question with varying empirical methodologies including reduced form regressions, micro and macro growth regressions, event studies, and growth accounting and structural change accounting. In this large literature, we believe one of the most important is Rodriguez and Rodrik (2001). Rodriguez and Rodrik (RR) demonstrated that some of the leading empirical research that found a strong role for trade policy had either flaws in the methodology or results that were not robust. Two of RR's prescriptions for future research were to study contingent relationships and to study the "channels through which trade policies influence economic performance." Our methodology is consistent with these prescriptions. We conduct a case study, i.e., a particularly sharp contingent relationship, and by using a structural model, we study several channels by which trade can influence growth. 
On the theoretical side, the last 20 years has seen the development of the endogenous and semiendogenous growth frameworks and the numerous models engendered by them. However, very few models have been applied to study actual growth experiences, including the growth miracles. ${ }^{2}$ While our model is not a direct descendant of the endogenous or semi-endogenous growth literature, we believe our neoclassical framework is a useful one and provides a benchmark for further studies using the more modern frameworks.

The next section presents the model and discusses the core intuition of the effects of trade barrier reductions. Section 3 provides the calibration of the model along with the key facts and policies that are used to both calibrate and evaluate the model. This is followed by the simulation of the trade liberalizations and the results. The final section concludes.

\section{The Model}

In this section, we describe the model. The model combines neoclassical trade with neoclassical growth. In a neoclassical trade framework, comparative advantage and the costs of international trade determine the pattern of production, specialization, and trade. We employ a Ricardian setting that draws from Eaton and Kortum $(2002)$, as well as Yi $(2003,2008) .{ }^{3}$ In the neoclassical growth framework, aggregate TFP and the stock of capital determine per capita output. The link between these two frameworks is that trade barrier reductions - by facilitating the reallocation of resources to their most efficient use - will increase aggregate TFP in the economy. If the trade barrier reductions also facilitate imports of investment goods, the aggregate capital stock will increase. Trade will increase of course, as well. A channel that can potentially accentuate the effect of trade barrier reductions is multi-stage production and the possibility of vertical specialization. Below, we first lay out the benchmark model, then we describe some of the key transmission channels. We also show how the model is modified to allow for one of Korea's trade policy reforms.

\subsection{Technologies}

There are two countries, $\mathrm{H}$ and $\mathrm{F}$. There are two sectors, an investment goods sector and a consumption-cum-intermediate goods sector. (Hereafter, we will refer to the second sector as the consumption sector.) Each sector consists of a continuum of goods. An investment good $z \in[0,1]$

\footnotetext{
${ }^{2}$ Several closed economy models of growth have been calibrated, some even to the Korean experience. See, for example, Papageorgiu and Perez-Sebastian (2006). However, to our knowledge there have been little or no studies in an open economy setting.

${ }^{3}$ See also Alvarez and Lucas (2007) and Waugh (2007).
} 
is produced from capital, labor, and the aggregate intermediate good. These investment goods are costlessly combined to yield an aggregate, non-traded, investment good that adds to the economy's capital stock. A consumption good $z \in[0,1]$ is produced in two sequential stages, i.e., there is multi-stage production of consumption goods. ${ }^{4}$ First, capital, labor and the aggregate intermediate are combined to make a "stage 1" good. Then, the stage 1 good is combined with capital and labor to make the "stage $2 "$ good. These stage 2 goods are costlessly combined to yield an aggregate, non-traded good used for consumption and as an intermediate in production. All stages of the continuum of investment and consumption goods are tradable. Only the aggregate goods are non-tradeable.

The production function for stage 1 consumption goods is given by:

$$
y_{i 1}(z)=\left(A_{i 1}(z) k_{i 1}(z)^{\alpha} l_{i 1}(z)^{1-\alpha}\right)^{1-\theta_{1}} M_{i}(z)^{\theta_{1}} \quad z \in[0,1]
$$

where $A_{i 1}(z)$ is country $i$ 's total factor productivity associated with stage 1 good $z$, and $k_{i 1}(z)$, $l_{i 1}(z)$, and $M_{i}(z)$ are country $i$ 's inputs of capital, labor and aggregate intermediate $M_{i}$ used to produce $y_{i 1}(z)$. The share of intermediates in production is $\theta_{1} .{ }^{5}$ This first stage is a Cobb-Douglas version of the production function in Eaton and Kortum (2002) with value-added augmented to include capital.

The production function for stage 2 consumption goods is given by:

$$
\left.y_{i 2}(z)=A_{i 2}(z) k_{i 2}(z)^{\alpha} l_{i 2}(z)^{1-\alpha}\right)^{1-\theta_{2}} x_{i 1}(z)^{\theta_{2}} \quad z \in[0,1]
$$

where $x_{i 1}(z)$ is country $i$ 's use of $y_{1}(z)$ for stage 2 production, $A_{i 2}(z)$ is country $i$ 's total factor productivity associated with stage $2 \operatorname{good} z$, and $k_{i 2}(z)$ and $l_{i 2}(z)$ are country $i$ 's labor used in producing $y_{i 2}(z)$. Under autarky, $x_{i 2}(z)=y_{i 2}(z)$. The share of intermediates for this stage is $\theta_{2}$.

The stage 2 consumption goods are costlessly assembled to produce an aggregate non-traded good $X_{i}$, which is used for consumption, $C_{i}$, and as an intermediate in production, $M_{i}$ :

$$
X_{i}=\exp \left[\int_{0}^{1} \ln \left(x_{i 2}(z)\right) d z\right]=C_{i}+M_{i}
$$

\footnotetext{
${ }^{4}$ Eaton and Kortum (2001) show that capital goods production is dominated by a few advanced countries. Consequently, we assume these goods are produced in a single stage.

${ }^{5}$ The first stage of production in this model differs from that in Yi (2003) in its inclusion of intermediates. This facilitates matching both gross output, trade, and value-added (GDP) in the calibration.
} 
where $x_{i 2}(z)$ is the amount of the stage $2 \operatorname{good} z$ used to produce $X_{i}$.

Investment goods are also produced from capital, labor and the aggregate intermediate:

$$
y_{i I}(z)=\left(A_{i I}(z) k_{i I}^{\alpha}(z) l_{i I}(z)^{1-\alpha}\right)^{1-\theta_{1}} M_{i I}(z)^{\theta_{1}} \quad z \in[0,1]
$$

where $A_{i I}(z)$ is country $i$ 's total factor productivity (TFP) associated with the investment good $z$, and $k_{i I}(z), l_{i I}(z)$, and $M_{i I}(z)$ are country $i$ 's inputs of capital, labor and aggregate intermediate $M_{i}$ used to produce $y_{i I}(z)$. These investment goods are costlessly assembled into an aggregate non-traded investment good, $I_{i}$ :

$$
I_{i}=\exp \left[\int_{0}^{1} \ln \left(I_{i}(z)\right) d z\right]
$$

where $I_{i}(z)$ is country $i$ 's use of $y_{i I}(z)$ for production of $I_{i}$.

Note that the capital share of value-added is the same across all production functions and countries. This is a requirement for comparative advantage to be based solely on Ricardian motives. In a Ricardian trade model, comparative advantage is based on relative productivity differences across countries. That is, the TFP terms $A_{i 1}(z), A_{i 2}(z)$, and $A_{i I}(z)$ determine comparative advantage. Following Eaton and Kortum (2002), hereafter, EK, we model the TFPs as being drawn from a Frechét probability distribution:

$$
F\left(A_{i}\right)=e^{-T A_{i}^{-n}} \quad i=H, F
$$

The mean of $A$ is increasing in T. $n$ is a smoothness parameter that governs the heterogeneity of the draws from the productivity distribution. The larger $n$ is, the lower the heterogeneity or variance of $A$.

\subsection{Trade Costs}

When the stage 1 or stage 2 consumption goods or the investment goods are shipped from country $i$ to country $j$, they incur three types of trade costs, all expressed in ad valorem terms: tariffs, $b_{i j}$; transport costs, $d_{i j}$, and a stand-in for all other trade costs, $t r_{i j}$. Total trade costs are given by $1+\tau_{i j}=\left(1+b_{i j}\right)\left(1+d_{i j}\right)\left(1+t r_{i j}\right)$. The costs are modeled as iceberg costs. So, if 1 unit of a good $z$ is shipped from country $H$ to country $F$, for example, then $1 /\left(1+\tau_{H F}\right)$ units of $z$ arrive in country $F{ }^{6}$ We assume that within country trade costs are zero. $1+\tau_{i x}(z)$ denotes the shipping costs

\footnotetext{
${ }^{6}$ Tariff revenue is assume to be "tossed into the ocean".
} 
associated with country $i$ purchasing good $z$ of type $x$ (stage 1 consumption, stage 2 consumption, or investment) from its cheapest source, i.e., $1+\tau_{i x}=1+\tau_{j i x}$ if country $j$ is the cheapest source for country $i$ 's purchase. Note that the cheapest source for country $i$ 's purchase of stage 1 consumption good $z$ may not be the cheapest source for country i's purchase of stage 2 consumption good $z$ or of investment good $z$.

\section{$2.3 \quad$ Firms}

Firms maximize profits taking prices as given. Specifically, in each period, they hire capital and labor, and purchase inputs in order to produce their output, which they sell at market prices.

Stage 1 consumption good firms in country $i$ maximize:

$$
p_{i 1}(z) y_{i 1}(z)-w_{i} l_{i 1}(z)-r_{i} k_{i 1}(z)-P_{i} M_{i}(z)
$$

where $p_{i 1}(z)$ is the factory gate price of $y_{i 1}(z)$, and $w_{i}, r_{i}$ and $P_{i}$ are the wage rate, rental rate, and aggregate intermediate price, respectively, in country $i$.

Stage 2 consumption good firms in country $i$ maximize:

$$
p_{i 2}(z) y_{i 2}(z)-w_{i} l_{i 2}(z)-r_{i} k_{i 2}(z)-\left(1+\tau_{i 1}(z)\right) p_{i 1}(z) x_{i 1}(z)
$$

where $p_{i 2}(z)$ is the factory gate price of $y_{i 2}(z)$, and $1+\tau_{i}(z)$ is the total trade cost incurred in shipping the stage 1 good $z$ from country $i$ 's cheapest source to country $i$.

The consumption and intermediate good "aggregator" firm in country $i$ maximizes:

$$
P_{i} X_{i}-\int_{0}^{1}\left(1+\tau_{i 2}(z)\right) p_{j 2}(z) x_{i 2}(z) d z
$$

where country $j$ is the supplier of stage $2 \operatorname{good} z$ to country $i . P_{i}$ is the price of the aggregate consumption and intermediate good $X_{i}$.

Similarly, investment good firms in country $i$ maximize:

$$
p_{i I}(z) y_{i I}(z)-w_{i} l_{i I}(z)-r_{i} k_{i I}(z)-P_{i} M_{i I}(z)
$$


The investment "aggregator" firm in country $i$ maximizes:

$$
P_{i I} I_{i}-\int_{0}^{1}\left(1+\tau_{i I}(z)\right) p_{j I}(z) I_{i}(z) d z
$$

where country $j$ is the supplier of the investment good $z$ to country $i$. $P_{i I}$ is the price of the aggregate investment good $I_{i}$.

\subsection{Households}

The representative household in country $i$ maximizes:

$$
\sum_{t=0}^{\infty} \beta^{t} \frac{C_{i t}^{1-\sigma}-1}{1-\sigma}
$$

subject to a sequence of budget constraints:

$$
P_{i t} C_{i t}+P_{i I t} I_{i t}=w_{i t} L_{i t}+r_{i t} K_{i t}
$$

where $C_{i t}$ is consumption of the aggregate consumption good in period t. The elasticity of intertemporal substitution is $\frac{1}{\sigma}$. Households own the capital and rent it period-by-period to the consumption and investment goods firms. Note that we do not allow the countries to run current account deficits. ${ }^{7}$ Capital is accumulated in the standard way:

$$
K_{i t+1}=(1-\delta) K_{i t}+I_{i t}
$$

\subsection{Equilibrium conditions}

All factor and goods markets are characterized by perfect competition. The following factor market clearing conditions hold for each country in each period:

$$
L_{i}=\int_{0}^{1} l_{i 1}(z) d z+\int_{0}^{1} l_{i 2}(z) d z+\int_{0}^{1} l_{i I}(z) d z
$$

\footnotetext{
${ }^{7}$ In fact, Korea ran current account deficits during the 1960s and 1970s, and then balanced trade or surpluses beginning in the mid-1980s. Allowing for current account deficits would be a useful extension.
} 


$$
K_{i}=\int_{0}^{1} k_{i 1}(z) d z+\int_{0}^{1} k_{i 2}(z) d z+\int_{0}^{1} k_{i I}(z) d z
$$

The stage 1 consumption goods market equilibrium condition for each $z$ is:

$$
y_{1}(z) \equiv \sum_{i=1}^{2} y_{i 1}(z)=\sum_{i=1}^{2}\left(1+\tau_{i 1}(z)\right) x_{i 1}(z)
$$

where $1+\tau_{i 1}(z)$ is the total trade cost incurred by shipping the stage 1 good from country $i$ 's cheapest source to country $i$. The condition states that total production of the stage 1 good equals the total demand, inclusive of trade costs, for that good. A similar set of conditions applies to each stage 2 consumption good $z$ and each investment good $z$ :

$$
\begin{aligned}
& y_{2}(z) \equiv \sum_{i=1}^{2} y_{2}^{i}(z)=\sum_{i=1}^{2}\left(1+\tau_{i 2}(z)\right) x_{i 2}(z) \\
& y_{I}(z) \equiv \sum_{i=1}^{2} y_{i I}(z)=\sum_{i=1}^{2}\left(1+\tau_{i I}(z)\right) I_{i}(z)
\end{aligned}
$$

Finally, the aggregate consumption and intermediate good must be completely absorbed:

$$
X_{i}=C_{i}+M_{i}=C_{i}+\int_{0}^{1} M_{i}(z) d z++\int_{0}^{1} M_{i I}(z) d z
$$

If these conditions hold, then each country's exports equals its imports, i.e., balanced trade holds. We now define the equilibrium of this model:

Definition 1 An equilibrium is a sequence of goods prices, $\left\{p_{i 1}(z), p_{i 2}(z), p_{i I}(z), P_{i}, P_{i I}\right\}$; factor prices, $\left\{w_{i}, r_{i}\right\} ;$ factor inputs, $\left\{l_{i 1}(z), l_{i 2}(z), l_{i I}(z), k_{i 1}(z), k_{i 2}(z), k_{i I}(z)\right\}$; intermediate inputs, $\left\{M_{i}(z), M_{i I}(z)\right\} ;$ and outputs, $\left\{y_{i 1}(z), y_{i 2}(z), y_{i I}(z), x_{i 1}(z), x_{i 2}(z), I_{i}(z), C_{i}, I_{i}, M_{i}\right\}, z \in[0,1], i=$ $H, F$, such that the first order conditions to the households' maximization problem 11, the first order conditions to the firms' maximization problems 6-10, as well as the market clearing conditions 14-19 are satisfied. 


\subsection{Trade, Vertical Specialization, and Growth and Income}

\subsubsection{Trade}

Under autarky, each country produces the entire continuum of stage 1 consumption goods, stage 2 consumption goods, and investment goods. There is no specialization. Under completely free and frictionless trade - tariffs, transport costs, and all other trade costs are zero - then there will be complete specialization. Each stage of each good will be produced by only one country. Which country produces which stage of which good depends on the interplay of relative productivity differences across countries and relative factor costs. For example, consider an investment good $z$. There are two possible production methods, producing it in country $H$ or producing it in country $F$. The good will be produced in country $H$ if the following condition holds:

$$
p_{H I}(z) \equiv \frac{\psi\left(w_{H}^{1-\alpha} r_{H}^{\alpha}\right)^{1-\theta_{1}}\left(P_{H}\right)^{\theta_{1}}}{A_{H I}(z)^{1-\theta_{1}}}<\frac{\psi\left(w_{F}^{1-\alpha} r_{F}^{\alpha}\right)^{1-\theta_{1}}\left(P_{F}\right)^{\theta_{1}}}{A_{F I}(z)^{1-\theta_{1}}} \equiv p_{F I}(z)
$$

This can be rewritten as:

$$
\left(\omega^{1-\alpha} \rho^{\alpha}\right)^{1-\theta_{1}}\left(P_{H}\right)^{\theta_{1}}<\left(\frac{A_{H I}(z)}{A_{F I}(z)}\right)^{1-\theta_{1}}
$$

where $\omega=w_{H} / w_{F}, \rho=r_{H} / r_{F}$, and we treat the foreign aggregate consumption (and intermediate) good as the numeraire. The above equation essentially says that if the ratio of $H$ to $F$ production costs is less than the ratio of TFPs, the good will be produced in the home country. More generally, the world price of an investment $\operatorname{good} z, p_{I}(z)=\min \left[p_{H I}(z), p_{F I}(z)\right]$.

It will not be possible that one country produces all goods more cheaply, because in general equilibrium, wages and rental rates are determined so that each country's production equals its spending or, put differently, each country's exports equals its imports. Each country will find some goods for which the other country is the low cost producer. This is the essence of comparative advantage and general equilibrium.

Suppose that consumption and investment goods were produced only in a single stage. If both countries had the same labor endowment, and if both sets of productivities were drawn from the same Frechét distribution, then in equilibrium wages and rents would be equalized, and the export share of GDP would be $1 / 2$. Each country would specialize in half the goods, and would import the other half.

For consumption good $z$, there are four possible production methods: $H H, F H, H F$, and $F F$, where $F H$ means the first stage is produced in country $F$ and the second stage is produced in 
country $H$. If the second stage is produced in $H$, then $p_{H 2}(z)=\min \left[p_{H H}(z), p_{F H}(z)\right]$. Similarly, if the stage 2 good is produced in $F$, then $p_{F 2}(z)=\min \left[p_{H F}(z), p_{F F}(z)\right]$. Then, the world price of the good, $p_{2}(z)=\min \left[p_{H 2}(z), p_{F 2}(z)\right]=\min \left[p_{H H}(z), p_{F H}(z), p_{H F}(z), p_{F F}(z)\right]$.

If one country is relatively more productive at making investment goods than consumption goods, then it will specialize in investment goods, and run a trade surplus in those goods and a trade deficit in consumption goods. However, owing to our distributional assumptions about the productivities, the country will not specialize only in investment goods. It will import some investment goods, and export some consumption goods. In this sense, there is intra-industry trade. ${ }^{8}$

In the presence of trade costs, there will no longer be complete specialization. Some stages of some goods will be made by both countries, as each will find it cheaper to purchase its own goods rather than pay relatively high shipping costs to import an otherwise cheaper good. Trade shares of output are lower. A key force determining the elasticity of trade with respect to trade costs is the parameter $n$ from the Frechét distribution, which determines the variance of heterogeneity in productivities. If $n$ is low, there is a great deal of heterogeneity, which makes it likely that one country is much more productive at making a good than the other country. This means specialization and trade patterns will not respond too much to changes in trade costs. The opposite is true if $n$ is high. Eaton and Kortum (2002) show that $n$ plays the same role in their model as $\sigma-1$, where $\sigma$ is the elasticity of substitution between goods, in the monopolistic competition or Armington aggregator-based trade models.

\subsubsection{Vertical Specialization}

For consumption goods, the presence of multi-stage production leads to the possibility of vertical specialization. In previous research, D. Hummels, J. Ishii, D. Rapoport, and one of us have documented the increasing importance of vertical specialization in OECD and other countries. ${ }^{9}$ Hummels, Ishii, and Yi (2001) define vertical specialization as:

1. Goods are produced in multiple, sequential stages.

2. Two or more countries provide value-added in the good's production sequence.

3. At least one country must use imported inputs in its stage of the production process, and some of the resulting output must be exported.

\footnotetext{
${ }^{8}$ See Davis (1995), which is, to our knowledge, the first model of intra-industry trade in a perfect competition, comparative advantage setting.

${ }^{9}$ See Hummels, Rapoport, and Yi (1998), Hummels, Ishii, and Yi (2001), and Yi (2003).
} 
Figure 3: Vertical Specialization

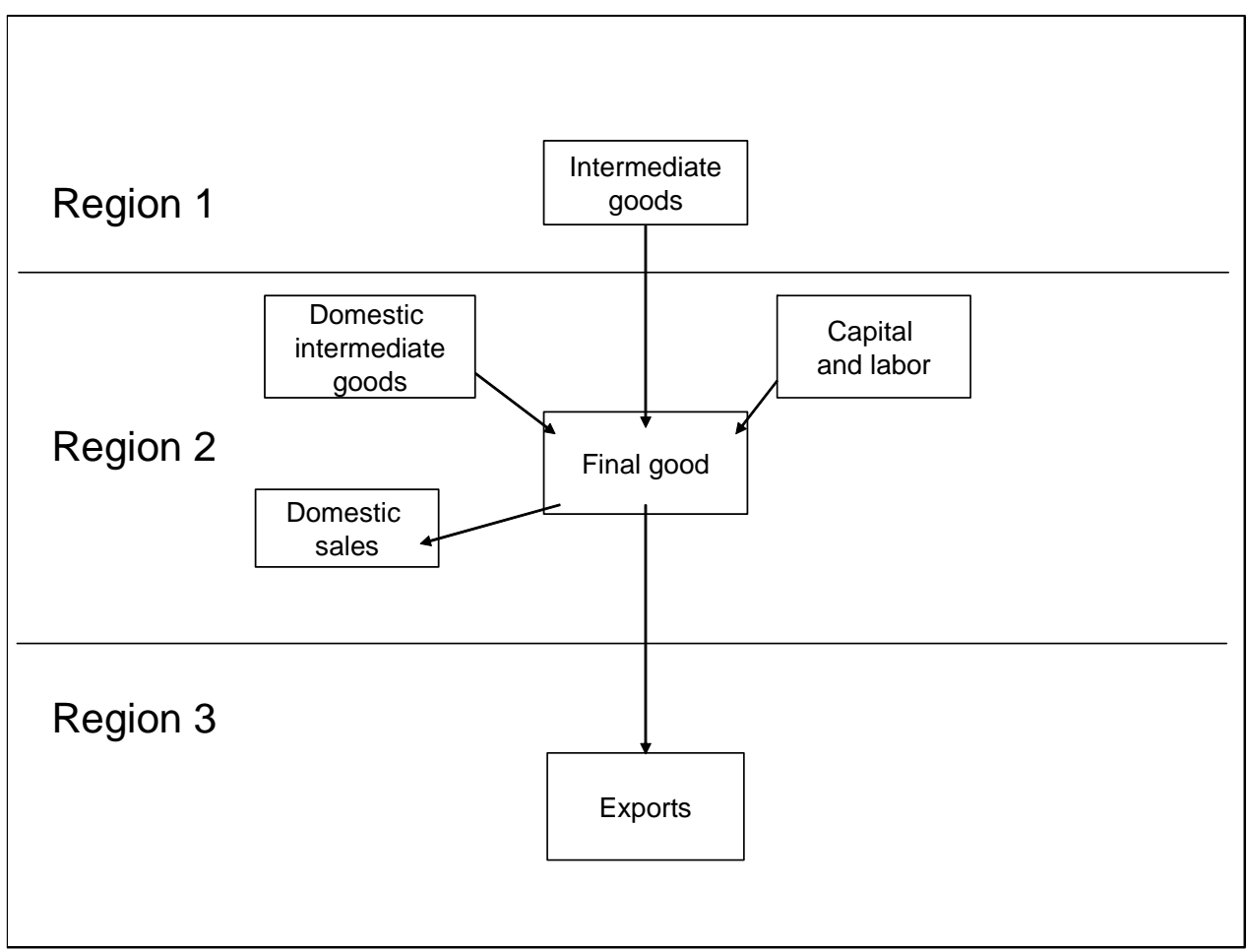

Figure 3 illustrates an example of vertical specialization involving three countries. Country 1 produces intermediate goods and exports them to country 2. Country 2 combines the imported intermediates with other inputs and value-added to produce a final good or another intermediate good in the production chain. Finally, country 2 exports some of its output to country 3 . If either the imported intermediates or exports are absent, then there is no vertical specialization.

A necessary condition for vertically specialized production of a good to occur is for one country to be relatively more productive in the first stage of production and another country to be relatively more productive in the second stage. By this definition, goods produced by production method $F H$ and exported back to country $F$ or goods produced by production method $H F$ and exported back to country $H$ are vertically specialized.

Hummels, Ishii, and Yi (HIY) develop two measures of vertical specialization. Their primary measure is $V S$ :

$$
V S_{k i}=\left(\frac{\text { imported intermediates }_{k i}}{\text { Gross output }_{k i}}\right) \text { Exports }_{k i}
$$

where $k$ and $i$ denote country and good, respectively. The measure is essentially the imported intermediates content of exports. HIY use data from input-output tables to come up with industry- 
Figure 4: Korea VS as share of merchandise GDP

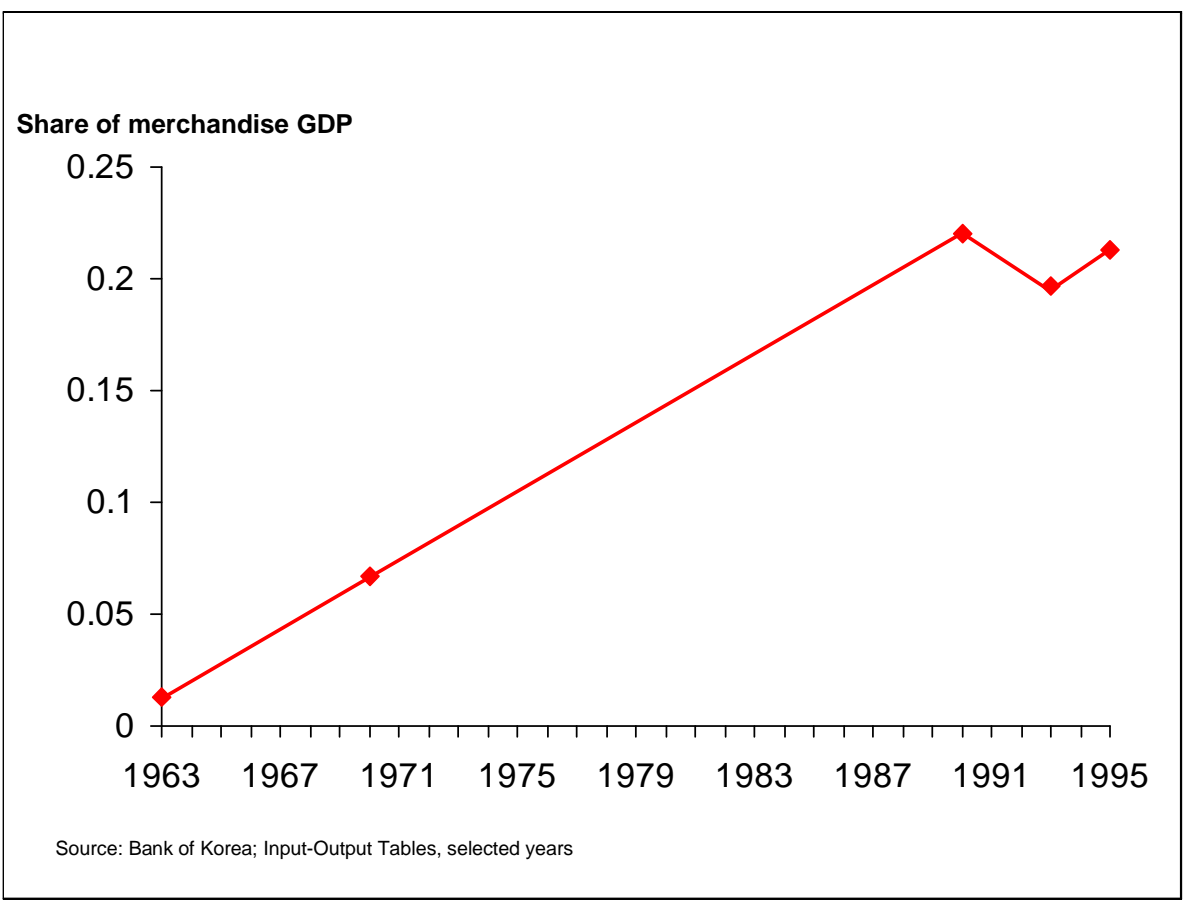

level and national measures of vertical specialization for several countries over time. ${ }^{10}$ Figure 4 illustrates $V S_{\text {korea }}$ expressed as a share of merchandise GDP. The figure shows that it rose rapidly in Korea from around 0.01 to 20 times that by the 1990s.

Clearly, growth in vertical specialization has been a large part of Korea's trade experience. This is the reason we model consumption goods production as a multi-stage process. Yi (2003) demonstrates that with multi-stage production and vertical specialization, the effects of trade barrier reductions on trade are magnified. Here, we provide a simple example to illustrate this point and describe the intuition underlying it.

Consider a special case of the model in which the countries are symmetric and there is only one sector, the consumption goods. The capital stock is exogenous and fixed. We assume that the two countries have the same capital and labor endowments, the same underlying distribution of TFPs for each stage of production, and the same trade costs. This implies that wages, rents, and GDPs are equalized across countries. We also assume that the first stage of production is produced in the country that ultimately purchases the second stage good; only the second stage production location

\footnotetext{
${ }^{10} \mathrm{An}$ additional advantage of using input-output tables is that they facilitate measuring the indirect import content of exports. Inputs may be imported, for example, and used to produce an intermediate good that is itself not exported, but rather, used as an input to produce a good that is. See Hummels, Ishii, and Yi (2001).
} 
is determined by the model. Thus, if an $H$ aggregator firm seeks to purchase an automobile, the parts and components are assumed to be produced in $H$, while final assembly can occur either in $H$ or $F$. This assumption ensures that an analytical expression for the import share of GDP exists.

For goods consumed by the home country, the two possible production methods are $H H$ and $H F$. Note that production method $H F$ involves international vertical specialization: the foreign country imports inputs and exports its resulting output back to $H$. Following Dornbusch, Fischer, and Samuelson (1977) we can arrange the stage 2 goods in descending order of the ratio of home to foreign productivity of stage 2 production. International imports for the home country expressed as a share of GDP are given by:

$$
\varphi\left(1-\underline{z}_{h}\right)
$$

where $\underline{z}_{h}$ denotes the cutoff that separates home and foreign production of stage 2 goods for the home market. $\varphi$ is a constant that depends on $\theta_{1}$ and $\theta_{2}$. In the appendix, we show that the solution for $\underline{z}_{h}$ is given by:

$$
\underline{z}_{h}=\frac{(1+\tau)^{n\left(\frac{1+\theta_{2}}{1-\theta_{2}}\right)}}{1+(1+\tau)^{n\left(\frac{1+\theta_{2}}{1-\theta_{2}}\right)}}
$$

Then, the import share of GDP is:

$$
\frac{\varphi}{1+(1+\tau)^{n\left(\frac{1+\theta_{2}}{1-\theta_{2}}\right)}}
$$

Note that the responsiveness of the import share of GDP to trade costs depends on the "elasticity" $n$, and also on the term $\left(\frac{1+\theta_{2}}{1-\theta_{2}}\right)$, which shows that multi-stage production magnifies the effects of trade costs. If If $\theta_{2}=2 / 3$, for example, the exponent on the border cost is five times larger than in a one-stage model. As discussed in Yi (2008), two forces underlie the $\left(\frac{1+\theta_{2}}{1-\theta_{2}}\right)$ term. The first force is a "back-and-forth" force. With the $H F$ production process, the first stage encounters trade costs twice; recall that the share of stage 1 goods in stage 2 production is $\theta_{2}$. Consequently, the total effect of the trade cost owing to this force is $1+\theta_{2}$. The second force is an "effective rate of protection" force, because the concept is analogous to the concept from the literature of that name. The trade-off between $H H$ and $H F$ hinges on the second stage of production. The key idea is that the relevant or effective border cost is the border cost divided by the share of the second stage's value-added in the total cost. This is because the second stage is the marginal production stage, but the trade cost is applied to the entire good. If the second stage value-added 
accounts for one-third of the total cost, for example, then the effective border cost is three times the nominal border cost. This explains the $\frac{1}{1-\theta_{2}}$ term. ${ }^{11}$ Note that the magnification of trade costs is independent of the intermediate input share $\theta_{1}$. The presence of intermediates is necessary, but not sufficient, for a magnification effect.

\subsubsection{Growth and Income}

In this paper, we focus on the steady-state. ${ }^{12}$ Long run per capita income growth in our model is driven by long run growth in TFP. In this context, our primary growth assumption is that the growth rate of the parameter that governs the mean productivity, $T$, is constant across the two countries. That is, the two countries have identical long run per capita growth rates.

The goal of our paper is to focus on Korea's catch-up in per capita income to the G7. Hence, with no loss of generality, we set the long run growth rate of $T$ to be zero. We also assume that the labor endowments are constant over time. Hence, here is no overall or per capita growth in the steady-state. What determines the level of per capita income? The key equation arises from the consumption Euler equation. For the home country steady-state, it is:

$$
\frac{r_{h, s s}}{P_{h I, s s}}=\frac{1}{\beta}-(1-\delta)
$$

All else equal, the lower the steady-state price index for investment goods, $P_{h I, s s}$, the lower the required rate of return on capital, leading to a higher capital stock and a higher per capita income. $P_{h I, s s}$ is given by:

$$
P_{h I, s s}=\exp \left(\int_{H^{I}} \ln \left(p_{h I}(z)\right) d z+\int_{F^{I}} \ln \left(\left(1+\tau_{H I}\right) p_{F I}(z)\right) d z\right)
$$

where $H^{I}$ denotes the set of goods $z$ such that the lowest cost production source is in $H$. A reduction in trade costs, such as tariffs, lowers $P_{h I, s s}$ through two channels. There is a direct channel arising from the fact that lower tariff rates lowers the costs of imported investment goods, leading to a

\footnotetext{
${ }^{11}$ Another way to explain the $\left(\frac{1+\theta_{2}}{1-\theta_{2}}\right)$ term is via the following decomposition. In the $H F$ production process, the first stage encounters trade costs when it is shipped to the foreign country. The trade costs are equivalent to a cost on the second stage of production of $(1+\tau)^{\frac{\theta_{2}}{1-\theta_{2}}}$. Trade costs are encountered again when the final good is shipped back to the home country from the foreign country. Now the trade cost is applied to the entire good. Consequently, a cost of $1+\tau$ is imposed on the entire $H F$-produced good, which is effectively a cost of $(1+\tau)^{\frac{1}{1-\theta_{2}}}$ on the second stage of production. The total effect is the product of these two forces. If trade costs fall, the cost of producing vertically specialized goods declines by a multiple of the fall. See Yi (2008).

${ }^{12}$ We leave an analysis of transition dynamics to future work.
} 
reduction in the overall price index. There is a second channel in which the lower tariff rates will lead to a shift from relatively high cost domestic investment goods to relatively low cost imported investment goods. Hence, $H^{I}$ falls and $F^{I}$ rises. Through both these channels, lower trade costs raises trade including imports of investment goods. Because there is more specialization, there is more efficient resource allocation, leading to an increase in aggregate TFP, which also provides a further boost to capital accumulation. Note that aggregate TFP rises even though there has been no change in the efficiency of producing individual goods.

Another force leading to higher per capita income is an increase in $r_{h, s s}$. This could come about, for example, via a reduction in tariffs in country $F$. At existing factor and goods prices, country $F$ will demand more imports of consumption and investment goods from $H$. This will raise the demand for factors of production, thus bidding up wage and rental rates in $H$. The increase in $r_{h, s s}$ will lead to greater capital accumulation. The higher factor prices leads to an overall increase in $P_{h I, s s}$, but this only partially offsets the increase in capital accumulation. As above, because the lower tariffs leads to a better allocation of resources, aggregate TFP will rise, thus further boosting capital accumulation.

In general, reductions in tariffs on consumption goods will raise aggregate TFP, and any capital accumulation will be a result of the TFP increase, while reductions in tariffs on investment goods will raise capital accumulation with little effect on aggregate TFP.

\subsection{Implementing Korea's Tariff Exemption on Imported Inputs and Invest- ment Goods}

The model presented above will be used to characterize the initial steady-state, prior to the implementation of the trade policy reforms. One of Korea's major tariff reforms, as discussed in the introduction, was to exempt imported inputs and investment goods from tariffs, as long as these imports were used to make goods for export. That is, the price that Korean firms pay for these goods depended on their ultimate destination. To implement this policy reform, the model we laid out above needs to be modified. We introduce a second capital stock for $H, K_{H}^{E}$, that is used only to make goods via production method $F H$ and that are exported. ${ }^{13}$ This second capital stock is accumulated via a second investment good, $I_{H}^{E}$, which is an aggregate of the continuum of investment goods, as before, but any imported investment goods are imported duty-free. The

\footnotetext{
${ }^{13}$ We associate imported capital goods with production processes that also use imported inputs. In principle, there could have been production processes using only domestic inputs that relied on imported capital, but our sense is that this was not common until much later in Korea's development process. See Rhee and Westphal (1977).
} 
"aggregator" firm maximizes:

$$
P_{H I}^{E} I_{H}^{E}-\int_{0}^{1}\left(1+\tau_{H I}^{E}(z)\right) p_{j I}(z) I_{H}^{E}(z) d z
$$

where $P_{i I}^{E}$ and $I_{H}^{E}$ are the price and quantity of this second aggregate investment good, $\tau_{H I}^{E}(z)$ is the trade costs involved with purchasing an individual investment good, and $I_{H}^{E}(z)$ is the quantity purchased of an individual investment good. The budget constraint for the household in country $H$ is now:

$$
P_{H t} C_{H t}+P_{H I t} I_{H t}+P_{H I t}^{E} I_{H t}^{E}=w_{H t} L_{H t}+r_{H t} K_{H t}+r_{H t}^{E} K_{H t}^{E}
$$

where $r_{H t}^{E}$ is the rental rate on the aggregate export capital stock. The other maximization problems and equilibrium conditions are adjusted accordingly.

\section{Calibration to Korea and G7}

We now calibrate the model presented in sections 2.1-2.5. The two countries $H$ and $F$ are Korea and the G7 countries. The latter were recipients of $74 \%$ of Korea's exports and shipped $86 \%$ of Korea's imports in 1962. We focus on the manufacturing sector only. That is, we apply our model to the manufacturing sectors of the two countries. Our coverage is from 1962 through 1995, the period that constitutes the growth miracle and that precedes the Asia financial crisis. ${ }^{14}$ We assume that Korea was in a steady-state in 1962 in which the current tariff rates are expected to remain forever. Then there is an unexpected tariff reform, e.g., the reduction in Korean tariffs to their 1989 value - and this new policy is expected to remain in place forever. We also assume that there are no distortions in the economy other than the trade barriers. This is primarily for convenience. However, as discussed later, Westphal and Kim (1977) demonstrate that Korean exporters operated in a free-trade environment (once the reforms were implemented).

The parameters and variables that are calibrated include the labor endowments $L_{i}$ of each country; the intermediate input shares $\theta_{1}$ and $\theta_{2}$, the capital income share, the Frechét heterogeneity parameter $n$, the Frechét mean productivity parameters $T$, capital depreciation rate, preference discount factor, intertemporal elasticity of substitution, and the trade cost measures for each country and sector. The trade costs include tariff rates, transport costs, and all other trade costs.

\footnotetext{
${ }^{14} 1962$ is a desirable starting date, because it is the first full year after Park took office. However, much of our initial data is available only for 1963 .
} 
The underlying calibration strategy is straightforward. The labor endowments, intermediate input shares, capital income share, tariff rates and transport costs are set to match their data counterparts in 1962 or 1963 . The Frechét heterogeneity parameter $n$, capital depreciation rate, preference discount factor, and intertemporal elasticity of substitution are taken from the existing literature. The Frechét mean productivity parameters for the consumption and investment sectors and "all other" trade costs for consumption goods and investment goods are set so that the model matches Korea's initial relative per worker output, export share of GDP, and shares of trade that correspond to investment goods and final consumption goods. The challenge for the model is whether the tariff liberalizations will replicate the per worker output, trade, vertical specialization and TFP catch-up that is in the data.

We begin by describing our measures of transport costs and tariff rates. We then show how we calibrated the other variables and the parameters of the model.

\subsection{Transport Costs and Tariff Rates}

We now construct the data counterpart of the trade costs between country $i$ and country $j, \tau^{i j}=$ $\left(1+b_{i j}\right)\left(1+d_{i j}\right)\left(1+t r_{i j}\right)$. For transport costs, $d_{i j}$, we use Korea's cif imports / fob imports ratio in 1962, obtained from the 1992 IMF IFS yearbook. The difference between the two measures of imports is primarily the insurance and freight costs. In 1962, the difference was equal to 9.2 percent of Korea's fob imports. We assume these costs apply to Korea's exports, as well. Because our focus is on the effects of tariff reductions, we hold the transport costs constant over time.

We obtain measures of Korean tariff rates from Nam (1995). As import weighted-average tariff rates are well known to have downward biases, we use his simple average measure. He reports this average for several years between the early 1960s and the mid 1990s. The average tariff rate was 39.9 percent in 1962 and remained at a high level until the 1970s. Thereafter, it declined steadily to 12.7 percent in 1989. We obtain measures of G7 manufacturing tariff rates from Yi (2003). This is an average of the United States tariff and a tariff measure that is a weighted average of Japan and European Community tariff rates. ${ }^{15}$ These tariffs apply to both consumption goods and investment goods. The initial and post-reform tariff rates are listed in Table 1 below.

\footnotetext{
${ }^{15}$ The Korean tariff measure is for merchandise, rather than manufacturing. Agriculture and mining tariffs appear to constitute a small number of the total number of goods, so that while these tariffs tend to be lower than manufacturing taiffs, we do not believe this discepancy will exert more than a minor influence on our results. In addition, our G7 measure excludes Canada, but includes countries outside the G7. However, because these countries are not large, we believe that this discrepancy will also not exert a large effect on our results.
} 
Table 1: Tariff Rates (percent)

\begin{tabular}{|ccc}
\hline \hline & \multicolumn{2}{c}{ Country } \\
\cline { 2 - 3 } & Korea & G7 \\
1962 & 39.9 & 13.95 \\
1989 & 12.7 & 5.00 \\
& & \\
\hline Sources: Nam (1995) and Yi (2003)
\end{tabular}

We have no independent measure of "all other" trade costs. Consequently, we calibrate two trade costs, $t r_{i j, C}$ and $t r_{i j, I}$, one for consumption goods and one for investment goods, as part of our overall calibration of four key variables and parameters to four targets. This is discussed further below.

\subsection{Calibration of Other Variables and Parameters}

We calibrate the labor endowments $L_{i}$ to match manufacturing employment in Korea and the G7 in 1963. We begin with the measures of workers from the Penn World Tables (PWT) version 6.1. We use the Bank of Korea's Economic Statistics Yearbook to obtain the manufacturing share of employment in 1963 and multiply that by Korea's employment from the PWT. This yielded 743.3 thousand manufacturing workers. For the G7, we used the OECD's STAN database, which has manufacturing and total employment data for each of the G7 countries. However, this data start only in 1970. We assume the manufacturing share of employment in 1963 was the same as in 1970. We multiply this share by G7 employment from the PWT and obtain 62.13 million manufacturing workers.

Turning to the intermediate shares, $\theta_{1}$ and $\theta_{2}$, when $\theta_{1}=\theta_{2}=\theta$, it can be shown that the value-added/gross output ratio in each country is $1-\theta$. In Korea, the value-added/gross output ratio in 1963 was 0.31 . In the G7 nations, this ratio ranged from a low of 0.32 (Japan) to a high of 0.39 (United States). ${ }^{16}$ We set $\theta_{1}=\theta_{2}=\theta=2 / 3$.

The labor income share, $1-\alpha$, varies widely across countries. According to Young (1995), Korea's labor share of value-added in manufacturing was 0.504 percent in the early 1960s. From the STAN database, the labor share in 1970 ranged from a low of 0.399 (Japan) to 0.742 (United Kingdom). In the United States, it was 0.728. We set $\alpha=0.4$.

\footnotetext{
${ }^{16}$ There was no data for West Germany in 1970 .
} 
The key trade elasticity parameter other than the intermediate shares is the heterogeneity in productivity parameter, $n$. As stated above, this corresponds to an elasticity of substitution in monopolistic competition or Armington aggregator models of $n+1 .^{17}$ (Hereafter, we refer to the elasticity-equivalent of the parameter.) This elasticity is assumed identical across countries. EK's estimates of $n$ range from 3.6 to 12.86. Other prominent estimates include Baier and Bergstrand (2001) and Head and Ries (2001), who estimate substitution elasticities of 6.43 and 7.9, respectively. In the previous section, we demonstrated that under multi-stage production the responsiveness of trade to trade costs depends on both the elasticity of substitution and the "magnification effect". Consequently, existing estimates of the substitution elasticity may be upwardly biased. Hence, we set $n=4$.

Three dynamic parameters are set by using values from related research. Ogaki, Ostry, and Reinhart (1996) estimate the intertemporal elasticity of substitution, $1 / \sigma$, to be 0.6 . for developing countries. The next two parameters are drawn from Backus, Kehoe, and Kydland (1994). We set the annual capital depreciation rate, $\delta$, to $0.1 .^{18}$ Finally, we set $\beta$, the preference discount factor, to 0.96 , which corresponds to a real interest rate in steady-state of a little more than 4 percent.

The final parameters to specify are the Frechét mean productivity parameters, $T_{i C}$ and $T_{i I}$, for the two countries, and for two consumption stages and one investment stage - six parameters and "all other" trade costs, $t r_{i j, C}$ and $t r_{i j, I}$, for consumption goods and investment goods. With no loss of generality, we normalize the productivity parameters for the United States consumption and investment sectors to 1 . We assume that Korea has no particular comparative advantage in stage 2 production relative to stage 1 production. This leaves two productivity parameters and the two trade costs. We set these parameters and costs so that they meet four targets: Korea / G7 manufacturing output per worker; Korean export share of GDP; share of imported investment goods in Korea's GDP; share of Korea's imports that are consumption goods. ${ }^{19}$ In other words, we set these parameters and costs so that the model-implied steady-state for Korea in 1963 matches the key facts about Korea's per worker output and trade in manufacturing. Table 2 lists all the calibrated parameters and variables.

\footnotetext{
${ }^{17}$ See Eaton and Kortum (2002, p. 1750, fn. 20) or Anderson and van Wincoop (2004, p. 710).

${ }^{18}$ Given that most investment goods produced by the manufacturing sector is equipment, a higher depreciation rate might be warranted. We solved the initial steady-state, as well as the effects of all three trade reforms, using the equipment depreciation rate from Jorgenson, Gollop, and Fraumeni (1987), 0.13. The results were virtually identical.

${ }^{19}$ Hitting these targets also implies that the model will match the share of intermediates in Korean trade.
} 
Table 2: Other Calibrated Parameters and Variables

\begin{tabular}{|c|c|c|}
\hline Parameter & & Value \\
\hline Korea labor, $L_{\text {Korea }}$ & & 0.7433 \\
\hline G7 labor, $L_{G 7}$ & & 62.13 \\
\hline Intermediate input share, $\theta_{1}=\theta_{2}$ & & $2 / 3$ \\
\hline Capital income share, $\alpha$ & & 0.4 \\
\hline Frechét heterogeneity, $n$ & & 4 \\
\hline Intertemp. elasticity of substit., $1 / \sigma$ & & 0.6 \\
\hline Capital depreciation rate, $\delta$ & & 0.1 \\
\hline \multirow[t]{2}{*}{ Preference discount factor, $\beta$} & & 0.96 \\
\hline & Targets in 1963 & \\
\hline$\left(\frac{T_{K o r e a, C} / L_{K o r e a}}{T_{G 7 C} / L_{G 7}}\right)$ & $\frac{Y_{\text {Korea }} / L_{\text {Korea }}}{Y_{G 7} / L_{G 7}}(0.1712)$ & 1.211 \\
\hline$\left(\frac{T_{K o r e a, I} / L_{K o r e a}}{T_{G 7, I} / L_{G 7}}\right)$ & Korea export share of GDP (0.1469) & 0.793 \\
\hline$t r_{i j, C}$ & Imported investment share of GDP (0.03991) & 0.672 \\
\hline$t r_{i j, I}$ & Consumption share of imports $(0.02523)$ & 0.172 \\
\hline
\end{tabular}

The last four rows of the table show the values of the productivity parameters and trade costs that enable the model to meet the four targets in the initial steady-state. For ease of interpretation, the productivity parameters are normalized relative to the labor force in each country. ${ }^{20}$ The values indicate that Korea has a comparative advantage at producing consumption goods over investment goods. Also, the all other trade costs for consumption goods (67.2 percent) are considerably higher than for investment goods (17.2 percent). This largely reflects the fact that Korea had an extensive quota system applied primarily to consumption goods. This shows up in the very low share of imports that were consumption goods (2.52 percent). Hence, the total trade cost for consumption goods, including tariffs, transport costs, and all other costs, in 1962 was $1.399 \times 1.092 \times 1.672-1=$ 155.4 percent.

\subsection{Solution}

Given the parameterization of the model in Table 2 and the trade cost data in Table 1, the model will deliver an equilibrium set of factor prices, goods prices, production quantities, trade flows, and vertical specialization flows. We first solve for the initial steady-state in 1963. This solution also

\footnotetext{
${ }^{20}$ In a closed economy Eaton and Kortum (2002) setting, doubling capital and labor reduces per capita income unless $T$ also doubles. When $T$ doubles, then, per capita income remains constant.
} 
includes the productivity parameters and trade costs that yield relative value-added per worker, trade share of GDP, and sectoral shares in trade that match their data counterparts in 1963. Then, we simulate the trade policy reforms, individually and in aggregate. Unlike in EK, an exact solution to the model cannot be computed. Instead, we must find an approximate solution. To do so, we approximate the $[0,1]$ continuum with 2,500,000 equally spaced intervals; each interval corresponds to one good or one stage of one good. Further details on the solution method are in the appendix.

\section{Results}

We now assess the quantitative importance of the three sets of tariff reductions in explaining Korea's catch-up to the G7 in GDP per worker and export share of GDP. We also assess whether the model can replicate the growth of Korea's vertical specialization, as well as the changing sectoral composition of its trade, and whether a Hall and Jones (1999) development accounting decomposition matches what is in the data.

We first present the initial steady-state along with the corresponding data:

Table 3: Initial Steady-State

\begin{tabular}{rrrrr|rr}
\hline \hline Variable & $\frac{Y_{K} / L_{K}}{Y_{G 7} / L_{G 7}}$ & $\frac{M}{Y}$ & $\frac{\operatorname{Inv}_{M}}{Y}$ & $\frac{\mathrm{Con}_{M}}{M}$ & $\frac{V S}{Y}$ & Kshare \\
Actual data (1963) & 0.171 & 0.147 & 0.0399 & 0.0252 & 0.01257 & 0.98 \\
Initial steady-state & 0.171 & 0.147 & 0.0399 & 0.0252 & 0.00505 & 1 \\
\hline Note: $Y$, GDP; $L$, labor; $M$, imports; $V S$, vertical specialization; Inv $M$ and Con $M$, \\
imported investment and consumption; Kshare, share of capital that is for domestic sales; \\
\hline
\end{tabular}

The first four columns were calibrated to match the data. Among the two columns on the right, note that the model implies an initial steady-state $V S / Y$ ratio that is about $2 / 5$ of what it is in the data, and an initial capital share devoted to domestic sales that is close to the true value of 0.98. These are two diagnostics that suggest the model is an appropriate one to analyze the effects of the three trade policy reforms.

The first two rows of table 4 present the actual data in 1963 and 1995, respectively. For relative output per worker, we report the logarithmic growth rate between 1963 and 1995. We refer to that growth rate, 0.837 , as Korea's "catch-up" in relative value-added per worker. Our first simulation is to implement the tariff exemption on imported inputs and investment goods as 
long as they are used to produce goods for export. Westphal and Kim (1977) compute effective rates of protection for Korean industries; they conclude that exporters faced essentially a free trade environment. Consequently, in implementing this simulation, we reduce all other trade costs, in addition to tariffs, to zero, as they likely represented other political barriers such as quotas and commodity taxes. Hence, trade costs for these goods are only the transport costs.

Table 4: Main Results

\begin{tabular}{r|rrrr|rr}
\hline \hline & \multicolumn{1}{c}{} \\
\hline Variable & $\Delta \ln \left(\frac{Y_{K} / L_{K}}{Y_{G 7} / L_{G 7}}\right)$ & $\frac{M}{Y}$ & $\frac{\operatorname{Inv}_{M}}{Y}$ & $\frac{\operatorname{Con}_{M}}{M}$ & $\frac{V S}{Y}$ & TFPshare \\
\hline Actual data (1963) & & 0.147 & 0.040 & 0.025 & 0.013 & \\
Actual data (1995) & 0.837 & 0.923 & 0.42 & 0.095 & 0.21 & \\
\hline (1) Tariff exemption & 0.0192 & 0.769 & 0.12 & 0.0069 & 0.17 & $<0$ \\
$(2)$ Korea tariff reduction & 0.0621 & 0.455 & 0.12 & 0.024 & 0.050 & 0.76 \\
$(3)$ GATT tariff reduction & 0.0139 & 0.224 & 0.060 & 0.025 & 0.012 & 0.75 \\
$(1)+(2)+(3)$ & 0.1724 & 1.656 & 0.24 & 0.0098 & 0.77 & 0.29 \\
$(1)+(2)+(3)+$ "leakage" & 0.2688 & 1.690 & 0.25 & 0.0037 & 0.81 & 0.62 \\
& & & & & & \\
\hline
\end{tabular}

Note: $Y$, GDP; $L$,labor; $M$, imports (exports); $V S$, vertical specialization; $\operatorname{Inv}_{M}$ and $\operatorname{Con}_{M}$,imported invest and consum; TFPshare, share of catch-up that is accounted for by TFP;

"leakage", imported inputs and investment goods are exempt from tariffs even for domestic sales;

The third row of Table 4 provides the results of this simulation. The tariff exemption generates a little more than 2 percent of the GDP per worker catch-up, a very small amount. Not surprisingly, this policy does better at capturing the increase in the export share of GDP with the model predicting a rise from 14.7 percent to 76.9 percent. In the data, it rose to 92.3 percent. The policy also does well at predicting the increase in vertical specialization. Relative to the initial steadystate, the model generates a tripling of the share of imported investment goods in GDP, but in the data it increased by a factor of 10 . The model delivers a counterfactual prediction on the change in the consumption share of imports, as well. Overall, this policy does fairly well in explaining the increases in trade, with the exception of the consumption share of imports; however, it has very little explanatory power for the catch-up in GDP per worker.

In the fourth row of the table, we examine the effects of the broad reduction in Korean tariffs. This policy captures about 6 percent of the GDP per worker catch-up, about three times more 
than the tariff exemption policy, although still a small fraction of the actual catch-up. However, the trade and vertical specialization shares of GDP rise by less than in the tariff exemption policy. The policy clearly delivers more "bang for the buck", in that a given increase in trade flows is associated with a considerably larger increase in GDP per worker catch-up.

Why does the tariff exemption have a much smaller "bang for the buck" than the broad Korea tariff reduction? With the tariff exemption, the aggregate investment good used to produce export goods becomes considerably cheaper than the aggregate investment good used to produce goods sold domestically. Hence, firms find it cheaper to substitute from domestic sales to export production. The share of capital that is for domestic sales declines from 1 to 0.753 . Indeed, the absolute level of domestic sales capital falls by about 20 percent. This substitution effect partially explains the small increase in output. In addition, the difference in prices between the two investment goods creates a distortion, which is why a fairly substantial increase in the capital/output ratio does not show up as output per worker gains. Indeed, aggregate TFP declines in this scenario. By contrast, virtually the opposite happens when there is a broad tariff reduction. Imports of investment goods increase, and they are allocated to their most efficient use, rather than only used with imported inputs and sold only for the export market. The aggregate TFP gains are much larger under a broad tariff reduction; as Table 4 shows, they account for about $3 / 4$ of the overall catch-up. ${ }^{21}$

The fifth row of the table presents the results from the GATT reduction in G7 tariffs. The reduction in tariffs in the ROW somewhat surprisingly has a small effect on Korea's catch-up and trade. These effects are smaller than those from the tariff exemption.

The next row presents the results from combining all three policies. The most interesting finding is that the effect of all three policies together on GDP per worker catch-up is about twice as large as the sum of the effects of each policy implemented individually. Taken together, the policies can explain about 21 percent of the catch-up. Clearly there is a positive interaction effect among these policies on output. If anything, one might have expected that the combined effect would be less than the sum of each, because the broad tariff reduction blunts the effect of the tariff exemption. ${ }^{22}$ There is an interaction effect on trade, as well. However, in this case the model over-predicts the export and vertical specialization shares of GDP by a factor of two and four, respectively. ${ }^{23}$ The model

\footnotetext{
${ }^{21}$ We employ the Hall and Jones (1999) method, which draws from Klenow and Rodriguez-Clare (1997), to compute the relative contribution of TFP and $\mathrm{K} / \mathrm{Y}$.

${ }^{22}$ The interaction effect also applies to each individual broad tariff reduction. That is, the catch-up when both the Korean and G7 tariff reductions are implemented simultaneously is considerably larger than the sum of the catch-up effects from the Korean tariff reduction and from the G7 tariff reduction.

${ }^{23}$ Koopman, Wang, and Wei (2008) show that in the presence of policies that explicitly encourage vertical specialization, the HIY methodology for computing VS underestimates the true level of VS. This suggests that the actual
} 
captures about half of the increase in the imported investment share of GDP, but counterfactually predicts that the consumption share of trade falls. Essentially, the tariff exemption encourages imported intermediates at the expense of imported consumption and investment goods.

In the early years of Korea's trade reforms government officials found it difficult to enforce the tariff exemption policy. Taken literally, the imported inputs and capital could not be used at all for production for domestic sale. In practice, owing to wastage allowances, cheating, and other forces, these inputs and capital were often used for domestic production and sale. Indeed, this led to a shift in policies over time from an outright exemption to a duty drawback type of policy in which exporters had to first pay the full price for imports and then file paperwork to claim the rebate. ${ }^{24}$ To model the "leakage" of these imported inputs and capital, we modify the tariff exemption policy to allow for duty-free importation of inputs and capital goods for domestic sale, as well. The results are reported in the sixth row. Now the trade policies can explain almost one-third of the catch-up. Moreover, the implications for the export share of output, vertical specialization, the imported investment share of GDP and the consumption share of imports, are about the same as in the previous simulation. Finally, the importance of TFP in accounting for the catch-up is considerably higher. ${ }^{25}$

In our simulations we hold the transport cost and the "all other" cost of importing consumption goods constant. Undoubtedly some of these costs were captured by quotas; over time the quotas were relaxed. For example, Korea went from a positive list quota system, in which goods not subject to quotas were explicitly listed, to a negative list system, in which goods subject to quotas were explicitly listed. In other words, under the new policy, the presumption was that goods would not be subject to quotas unless otherwise specified. Hence, this policy probably led to a greater share of consumption goods in imports than otherwise.

To understand further the quantitative importance of two key transmission channels, we engage in three further simulations. We first assess the importance of imported investment goods. Beginning from our initial steady-state, for 1963, we first shut down trade in investment goods. The effect is quite small; Korea's output per worker relative to that of the G7 falls by about 0.5 percent. This is not surprising, because Korea was not importing a lot of investment goods initially. A better

VS in Korea in 1995 was greater than the reported number, and the gap with this simulation smaller than indicated by the table.

${ }^{24}$ See Ianchovichina (2007) for an analysis of duty drawbacks.

${ }^{25}$ Applying the Klenow and Rodriguez-Clare (1997) methodology to the findings of Young (1995) yields the implication that close to $100 \%$ of Korea's growth in per capita output in manufacturing is accounted for by TFP growth. 
assessment of the importance of investment goods is to study the effects of the three trade policy reforms when trade in investment goods is not allowed. The fourth row of Table 5 presents the results of that simulation. For comparison, the third row presents the results of the three policies in the benchmark model. When trade in investment goods is not allowed, the catch-up in GDP per worker is only about $2 / 3$ as large relative to the benchmark model. Put differently, access to trade in investment goods generates close to a 50 percent larger catch-up. In addition, the model's implications for the growth in trade and vertical specialization are smaller - although they are closer to the actual growth rate.

Table 5: Further Results

\begin{tabular}{r|rrrr|r}
\hline \hline \multicolumn{1}{c}{ Variable } & $\Delta \ln \left(\frac{Y_{K} / L_{K}}{Y_{G 7} / L_{G 7}}\right)$ & $\frac{M}{Y}$ & $\frac{\operatorname{Inv}_{M}}{Y}$ & $\frac{\operatorname{Con}_{M}}{M}$ & $\frac{V S}{Y}$ \\
\hline Actual data $(1963)$ & & 0.147 & 0.040 & 0.025 & 0.013 \\
Actual data $(1995)$ & 0.837 & 0.923 & 0.42 & 0.095 & 0.21 \\
\hline$(1)+(2)+(3)$ & 0.172 & 1.656 & 0.24 & 0.0098 & 0.77 \\
$(1)+(2)+(3)$ without imported investment & 0.118 & 1.189 & 0.00 & 0.017 & 0.46 \\
$(2)+(3)$ without multi-stage production & 0.0561 & 0.241 & 0.19 & 0.21 & 0.00 \\
$(2)+(3)$ without multi-stage production and & 0.0116 & 0.104 & 0.00 & 1 & 0.00 \\
imported investment & & & & & \\
\hline
\end{tabular}

Note: $Y$, GDP; $L$,labor; $M$, imports (exports); $V S$, vertical specialization; $\operatorname{Inv}_{M}$ and $\operatorname{Con}_{M}$, imported investment and consumption

Second, we assess the importance of multi-stage production. Again, starting from the initial steady-state, we first shut down multi-stage production. Per worker output in Korea relative to the G7 falls by about 1 percent. We then implement the broad Korea tariff reduction and the GATT tariff reduction - the tariff exemption for imported inputs cannot be applied here - and compare it against the effects of these two policies in the benchmark model. The results are given in the fifth and sixth rows of the table. They show that multi-stage production facilitates almost a twice as large catch-up in GDP per worker. In addition, the implications for trade and vertical specialization, relative to the one-stage model, are considerably larger and closer to the 1995 data.

Finally, we assess the importance of imported investment goods and multi-stage production. When we shut down both channels, output per worker relative to that of the G7 falls by 2 percent. 
The results from implementing the two broad tariff reductions are given in the final row of Table 5 . Output per worker relative to the G7 rises by only 1.2 percent. The presence of these two channels, then, leads to a catch-up that is more than nine times larger; we conclude that imported investment and multi-stage production are responsible for almost 90 percent of the catch-up induced by these two broad tariff reductions.

Our simulations show that the broader tariff reductions have considerably more explanatory power for Korea's GDP per worker catch-up than the tariff exemptions policy. In addition, these policies together exert a stronger effect than the policies in isolation. Clearly, there is a positive interactive effect. The model does too well in explaining the growth of trade, but it falls short in explaining the catch-up. Nevertheless, the combined effect of all three policies is not small. Depending on whether "leakage" is allowed, the policies can explain 21 or 32 percent of the catchup. Further analysis shows that the twin channels of imported investment goods and multi-stage production explain almost 90 percent of Korea's catch-up induced by the two broad tariff reductions.

\section{Conclusion}

We study the effects of trade policy reforms on per capita gdp growth using a neoclassical model of growth and trade calibrated to South Korea and the G7 countries. South Korea's growth miracle in the three-plus decades following 1961 have been well-documented. There were three key trade reforms. Korea granted tariff exemptions on imported inputs and capital goods used to make export goods. Korea also engaged in a broad tariff reduction. Finally, the advanced nations, the recipients of most of Korea's exports, lowered their tariffs through two GATT rounds, the Kennedy and Tokyo rounds.

Our main finding is that these three policies account for about $1 / 5$ of Korea's catch-up in manufacturing GDP per worker. If duty-free imported inputs and capital goods are allowed for domestic production, as well, the policies can account for almost $1 / 3$ of the catch-up. In this latter case, aggregate TFP growth accounts for more than 60 percent of the catch-up. We also find an interaction effect among these policies; the combined effect on Korea's per worker is about twice as large as the sum of the effects of each individual policy. The trade reforms explain too much of Korea's trade and vertical specialization growth, however. Further experiments show that access to imported investment goods, as well as multiple stages of production and the additional specialization this engenders, are quantitatively significant in generating the above findings. 
We briefly describe two useful extensions. The first would be to study the effects of fiscal and financial reforms also oriented to exporters. This would require a setting in which distortions other than trade distortions are present. The second would be to expand the model beyond manufacturing by including primary commodities and services, either separately or jointly. This would enable the quantitative analysis to provide a more balanced and complete assessment of the role of trade policies in explaining Korea's growth miracle.

\section{A Appendix}

\section{A.1 Solution for $\underline{z}_{h}$ in the special case of the multi-stage production model case}

For goods ultimately consumed in the home country, there are two production methods, $H H$ and $H F$. Ordering the continuum of goods according to declining home country comparative advantage in stage 2 production, there is a cutoff $\underline{z}_{h}$ for which goods on the interval $\left[0, \underline{z}_{h}\right]$ are produced by $H H$, and goods on the interval $\left[\underline{z}_{h}, 1\right]$ are produced by $H F$. This cutoff is determined by the arbitrage condition that the price of purchasing this good (by a home country consumer) is the same across the two methods:

$$
\begin{aligned}
p_{H H}\left(\underline{z}_{h}\right) & \equiv\left(1+\tau_{H}\right) p_{H F}\left(\underline{z}_{h}\right) \Longrightarrow \\
\frac{\psi\left(w_{H}^{1-\alpha} r_{H}^{\alpha}\right)^{1-\theta_{1} \theta_{2}}\left(P_{H}\right)^{\theta_{1} \theta_{2}}}{A_{H 1}\left(\underline{z}_{h}\right)^{\left(1-\theta_{1}\right) \theta_{2}} A_{H 2}\left(\underline{z}_{h}\right)^{1-\theta_{2}}} & =\left(1+\tau_{H}\right) \frac{\psi\left(1+\tau_{F}\right)^{\theta_{2}}\left(w_{H}^{1-\alpha} r_{H}^{\alpha}\right)^{\left(1-\theta_{1}\right) \theta_{2}}\left(P_{H}\right)^{\theta_{1} \theta_{2}}\left(w_{F}^{1-\alpha} r_{F}^{\alpha}\right)^{1-\theta_{2}}}{A_{H 1}\left(\underline{z}_{h}\right)^{\left(1-\theta_{1}\right) \theta_{2}} A_{F 2}\left(\underline{z}_{h}\right)^{1-\theta_{2}}}
\end{aligned}
$$

where $\psi$ is a constant. Assuming $\tau_{H}=\tau_{F}$, and simplifying yields:

$$
\left(\omega^{1-\alpha} \rho^{\alpha}\right)^{1-\theta_{2}}=\left(\frac{A_{2}^{h}\left(\underline{z}_{h}\right)}{A_{2}^{f}\left(\underline{z}_{h}\right)}\right)^{1-\theta_{2}}(1+\tau)^{\left(1+\theta_{2}\right)}
$$

which leads to:

$$
\omega^{1-\alpha} \rho^{\alpha}=1=\left(\frac{1-\underline{z}_{h}}{\underline{z}_{h}}\right)^{\frac{1}{n}}(1+\tau)^{\frac{1+\theta_{2}}{1-\theta_{2}}}
$$

Solving for $\underline{z}_{h}$ yields (24).

\section{A.2 Solution Method}

We compute an approximate solution to the model. We approximate the $[0,1]$ continuum with 2,500,000 equally spaced intervals; each interval corresponds to one good or one stage of one good. We first solve for the initial steady-state, which includes the productivity parameters and trade costs that enable the model to match the four targets: relative per worker output, export share of GDP, investment import share of GDP, and consumption share of imports.

We then solve the model under different combinations of the trade reforms. We reduce the model to ten equations in ten unknowns (two wages, four aggregate price indices, three capital stocks and one aggregate intermediate). For each country, we draw a stage 1 productivity and a stage 2 productivity from the Frechét distribution for each of the 2,500,000 consumption goods and a productivity from the Frechét distribution for each of the 2,500,000 investment goods. We then calculate for each country the cheapest production method for each consumption good and 
each investment good. Finally, we assess whether the resulting pattern of production, trade, and prices is consistent with labor market equilibrium, capital market equilibrium, intermediates goods market equilibrium, and with the candidate aggregate prices. The model uses a Gauss-Newton algorithm to adjust the candidate vector until these conditions are met. The algorithm takes about 15 minutes in Gauss.

\section{References}

[1] Alvarez, Fernando, and Lucas, Jr., Robert E. "General Equilibrium Analysis of the EatonKortum Model of International Trade.” Journal of Monetary Economics, 2007, 54, 1726-68.

[2] Anderson, James E. and van Wincoop, Eric. "Trade Costs." Journal of Economic Literature, September 2004, 42, 691-751.

[3] Backus, David K., Kehoe, Patrick J., and Finn E. Kydland. "Dynamics of the Trade Balance and the Terms of Trade: The J-Curve?" American Economic Review, March 1994, 84 (1), 84-103.

[4] Baier, Scott and Bergstrand, Jeffrey. "The Growth of World Trade: Tariffs, Transport Costs, and Income Similarity.” Journal of International Economics, 2001, 53, 1-27.

[5] Bank of Korea, Economic Statistics Yearbook, various years.

[6] Davis, Donald R. "Intra-Industry Trade: A Heckscher-Ohlin-Ricardo Approach." Journal of International Economics, 1995, 39, 201-226.

[7] Dornbusch, Rudiger; Fischer, Stanley and Paul Samuelson. "Comparative Advantage, Trade, and Payments in a Ricardian Model with a Continuum of Goods." American Economic Review, 1977, 67, 823-839.

[8] Eaton, Jonathan and Kortum, Samuel. "Technology, Geography, and Trade." Econometrica, September 2002, 70 (5), 1741-1779.

[9] Eaton, Jonathan and Kortum, Samuel. "Trade in Capital Goods." European Economic Review, 2001, 45 (7), 1195-1235.

[10] Hall, Robert E. and Jones, Charles I. "Why Do Some Countries Produce so Much More Output per Worker than Others?" Quarterly Journal of Economics, February 1999, 114 (1), 83-116. 
[11] Head, Keith and Ries, John. "Increasing Returns Versus National Production Differentiation as an Explanation for the Pattern of U.S.-Canada Trade." American Economic Review, September 2001, 91 (4), 858-876.

[12] Hummels, David; Ishii, Jun and Kei-Mu Yi. "The Nature and Growth of Vertical Specialization in World Trade." Journal of International Economics, June 2001, 54, 75-96.

[13] Hummels, David; Rapoport, Dana and Kei-Mu Yi. "Vertical Specialization and the Changing Nature of World Trade." Federal Reserve Bank of New York Economic Policy Review, June 1998, 59-79.

[14] Ianchovichina, Elena. "Are Duty Drawbacks on Exports Worth the Hassle?" Canadian Journal of Economics, August 2007, 40 (3), 881-913.

[15] Jorgenson, Dale, Gollop, Frank, and Barbara Fraumeni. Productivity and U.S. Economic Growth. Cambridge, MA: Harvard University Press, 1987.

[16] Klenow, Peter, and Rodriguez-Clare, Andrés. "The Neoclassical Revival in Growth Economics: Has it Gone Too Far?" in Bernanke, Ben S. and Julio J. Rotemberg, eds., NBER Macroeconomics Annual 1997. Cambridge: MIT Press, 1997.

[17] Koopman, Robert; Wang, Zhi, and Shang-Jin Wei. "How Much of Chinese Exports is Really Made in China? Assessing Domestic Value-Added When Processing Trade is Pervasive." 2008, NBER WP 14109.

[18] Lee, Jong-Wha. "Government Interventions and Productivity Growth." Journal of Economic Growth, September 1996, 1, 391-414.

[19] Nam, Chong-Hyun. "The Role of Trade and Exchange Rate Policy in Korea's Growth." in Ito, Takatoshi and Anne O. Krueger, eds., Growth Theories in Light of the East Asian Experience. NBER East Asian Seminar on Economics Volume 4. Chicago: University of Chicago Press, 1995.

[20] Ogaki, Masao; Ostry, Jonathan D., and Carmen Reinhart. "Saving Behavior in Low- and Middle-Income Developing Countries: A Comparison." International Monetary Fund Staff Papers, March 1996, 43, 38-71. 
[21] Papageorgiou, Chris and Perez-Sebastian, Fidel. "Dynamics in a non-scale R\&D Growth Model with Human Capital: Explaining the Japanese and South Korean Development Experiences." Journal of Economic Dynamics and Control, 2006, 30, 901-930.

[22] Rhee, Yung W., and Westphal, Larry E. "A Micro, Econometric Investigation of Choice of Technology." Journal of Development Economics, 1977, 4, 205-237.

[23] Rodriguez, Francisco and Rodrik, Dani. "Trade Policy and Economic Growth: A Skeptic's Guide to the Cross-National Evidence." in Bernanke, Ben S. and Kenneth Rogoff, eds., NBER Macroeconomics Annual 2000. Cambridge: MIT Press, 2001.

[24] Waugh, Michael. "International Trade and Income Differences." manuscript, University of Iowa, November 2007.

[25] Westphal, Larry E. "Industrial Policy in an Export Propelled Economy: Lessons from South Korea's Experience.” Journal of Economic Perspectives, Summer 1990, 4, 41-59.

[26] Westphal, Larry E. and Kim, Kwang Suk. "Industrial Policy and Development in Korea.", 1977, World Bank Staff Working Paper 263.

[27] Yi, Kei-Mu. "Can Vertical Specialization Explain the Growth of World Trade?" Journal of Political Economy, February 2003, 111, 52-102.

[28] Yi, Kei-Mu. "Can Multi-Stage Production Explain the Home Bias in Trade?" Federal Reserve Bank of Philadelphia Working Paper 8-12, June 2008.

[29] Young, Alwyn. "The Tyranny of Numbers: Confronting the Statistical Realities of the East Asian Growth Experience." Quarterly Journal of Economics, August 1995, 110 (3), 641-680. 